\title{
AYAT-AYAT TENTANG ALAM
}

\author{
Ghafiki Faroek Abadi \\ (Mahasiswa S-3 UIN Sunan Ampel)
}

\begin{abstract}
Abstrak:
Penciptaan alam semesta dalam al-Qur'an dilengkapi dengan hukum-hukum Allah (sunnatullah) yang tidak akan mengalami perubahan dan penyimpangan. Oleh karena itu setiap manusia yang melaksanakan anjuran al-Qur'an agar memahami alam semesta dengan cara mengamatinya dengan alat indera atau dengan peralatan observasi, akal dan wahyu maupun ilham sehingga menyadari bahwa dibalik karya besar yang maha luas ini ada dzat yang harus diyakini dan disembah yakni Allah swt. Berbagai teori tentang terbentuknya alam semesta pada dasarnya tidak bertentangan dengan al-Qur'an, namun hasil yang ditemukan dari observasi ilmuwan yang kealaman yang dibidangi sains dan teknologi lebih akurat dan lebih dapat diterima daripada hasil pemikiran-pemikiran yang lain yang bersifat spekulatif. Karena alam semesta termasuk masalah alam fisik tidak dapat dilakukan dengan berpikir spekulatif, sebab memang bukan bidangnya. Menempatkan porsi ilmu yang tidak sesuai dengan bidangnya akan melahirkan kerancuan dan kebenarannya akan diragukan. Alam tunduk mutlak pada hukum-hukum Allah swt. Semua alam yang berjalan sesuai dengan hukumnya menjadi subyek sekaligus obyek pendidikan dan pembelajaran. Al-Qur'an memandang pengamatan indera sebagai saluran utama dalam memahami alam semesta. Namun dalam ayat-ayat lain, ditegaskan pula bahwa saluran ini belumlah cukup dan dibutuhkan saluran lain, yakni penalaran atau akal. Berbagai strategi pembelajaran dapat digunakan untuk
\end{abstract}


menyampaikan ayat al-Qur'an, sehingga dapat diterima dan dicerna oleh para peserta didik.

Kata Kunci: Teori Alam Semesta dan Ayat-ayat Al-Quran

\section{A. Pendahuluan}

Sudah menjadi kenyataan bagi umat Islam, bahwa Allah adalah pencipta (khaliq) dan alam semesta (universe) adalah ciptaan-Nya, namun mereka berbeda pendapat dalam memahami proses penciptaan. Penciptaan alam semesta termasuk salah satu perkara penting tidak hanya dalam bahasan bidang pemikiran Islam, akan tetapi juga dalam ilmu pengetahuan kosmologi. Dalam rekaman sejarah pemikiran Islam persoalan ini telah menjadi bahan polemik yang terkadang amat keras dan tajam.

Al-Qur'an kendatipun mengandung berbagai ragam masalah, ternyata pembicaraannya dalam satu masalah tidak tersusun secara sistematis seperti yang dikenal dalam bukubuku ilmiah. Metode pengungkapan al-Qur'an pada umumnya bersifat universal, bahkan tidak jarang al-Qur'an menampilkan suatu masalah dalam prinsip-prinsip pokok saja. Demikian juga halnya dengan informasi tentang alam semesta dalam alQur'an. Masalah ini tidak terhimpun pada satu kesatuan fragmen, tetapi diungkapkan dalam berbagai ayat yang tercantum dalam beberapa surat dalam al-Qur'an.

\section{B. Istilah Alam dalam al-Qur'an}

Istilah alam dalam al-Qur'an hanya datang dalam bentuk jamak 'alamin, disebut sebanyak 73 kali yang tercantum dalam 30 surat. Hal ini tercantum dalam surat alSyu'ara' dua belas kali, surat al-A'raf tujuh kali, surat Ali 'Imran 
dan al-'An'am lima kali, surat al-Baqarah dan al-'Ankabut empat kali, surah al-Maidah, al-Anbiya', al-Shaffat, dan Ghafir tiga kali, surat Yunus, al-Naml, al-Jathiyat dua kali, sedangkan surat al-Fatihah, Yusuf, al-Hijr, al-Furqan, al-Dukhan, alWaqi'at, al-Hyashr, al-Qalam, al-Haqat, al-Qashash, al-Sajdah, al-Zumar, Fusshilat, al-Zukhruf, Shad, dan Muthaffifin masingmasing satu kali. ${ }^{1}$

Ternyata kata 'alamin (jamak) dalam al-Qur'an tidak sama dengan istilah 'alam yang dimaksud kaum teolog dan kaum filosof Islam. Kaum teolog mendefinisikan 'alam ialah segala sesuatu selain Allah. Sementara kaum filosof Islam mendefinisikannya dengan kumpulan jauhar yang tersusun dari maddat (materi) dari shurat (bentuk) yang ada di bumi dan di langit. Sedangkan 'alamin yang dimaksudkan al-Qur'an, sebagai kumpulan yang sejenis dari makhluk Tuhan yang berakal atau memiliki sifat-sifat yang mendekati makhluk yang berakal. $^{2}$ Arti ini didasarkan pada kata 'alamin yang menunjukkan jamak al-mudhakkar yang berakal. Sebab itu dikenal alam malaikat, alam manusia, alam jin, alam tumbuhan dan lainnya, tetapi tidak dikenal istilah alam batu dan alam tanah, karena batu dan tanah tidak memenuhi kriteria di atas. Andai kata 'alamin dalam al-Qur'an itu sama dengan apa yang dimaksud kaum teolog dan kaum filosof Islam tentu saja tidak perlu digunakan bentuk jamak, padahal bentuk mufrad saja sudah cukup.

Sementara kata Rabb berarti pendidik atau pemelihara. Kata Rabb ini melukiskan Tuhan dengan segala sifat-Nya yang dapat menyentuh makhluk-Nya, seperti pemberian rezeki,

\footnotetext{
${ }^{1}$ Muhammad Fu'ad 'Abd al-Baqiy, al-Mu'jam al-Mufahras li Altfazhal-Qur'a>n alKarim, (Beirut: Dar al-Fikr, 1987), 480-481.

${ }^{2}$ Quraish Shihab, Hakikat Segala Puji Dalam Surah al-Fa>tihah, Amanah, Nomor 110 (21 September, 1990), 101.
} 
pengampunan, kasih sayang, juga amarah, ancaman, siksa dan sebagainya. Dengan demikian apapun bentuk perlakuan Tuhan kepada makhluk-Nya sama sekali tidak terlepas dari pemeliharaan dan pendidikan-Nya, kendatipun perlakuan-Nya menurut "kaca mata" manusia sebagai sesuatu yang negatif. ${ }^{3}$

Istilah untuk alam semesta (langit, bumi dan alam seisinya) atau universe, al-Qur'an mempergunakan istilah alsamawat wa al-ardh wa ma baynahuma. ${ }^{4}$ Dalam kumpulan wahyu Allah (al-Qur'an) istilah ini disebut sebanyak 20 kali yang tercantum dalam 15 surat, dengan rician: surat alDukhan dua kali, surat al-Hijr satu kali, surat Maryam satu kali, surat thaha satu kali, surat al-Furqan satu kali, surat alShu'ara' satu kali, surat al-Rum satu kali, surat al-Sajdah satu kali, surat al-Shaffat satu kali, surat al-Ahqaf satu kali dan surat al-Naba' satu kali.

Adapun contoh ayat yang menyebutkan kata alsamawat wa al-ardh wa ma baynahuma seperti yang termaktub dalam surat Maryam ayat: 65;

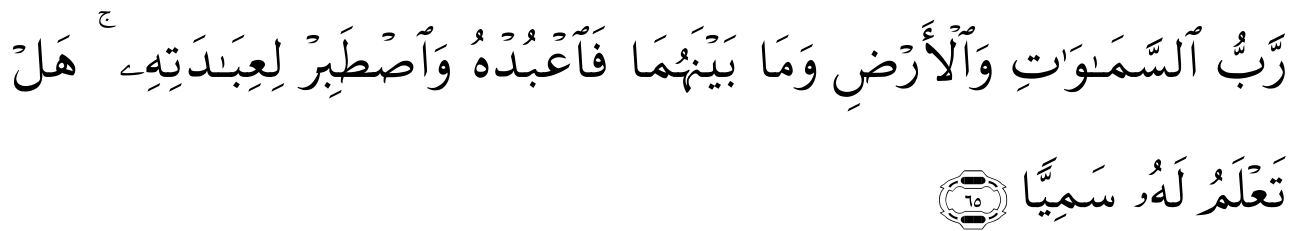

"Tuhan (yang menguasai) langit dan bumi dan apa-apa yang ada di antara keduanya, Maka sembahlah Dia dan berteguh hatilah dalam beribadah kepada-Nya. Apakah kamu mengetahui ada seorang yang sama dengan Dia (yang patut disembah)?" (Q.S. Maryam: 65). ${ }^{5}$

\footnotetext{
3 Sirajuddin Zar, Konsep Penciptaan Alam dalam Pemikiran Islam, Sains dan alQur'an, (Jakarta: PT. Raja Grafindo Persada, 1997), 20.

${ }^{4}$ Husein Bahreisy, Kamus Islam Menurut Qur'an dan Hadith, (Surabaya: Galundi Jaya, tt), 16.

5 Departemen Agama RI, Al-Qur'an dan Terjemahannya (Jakarta: Yayasan Penyelenggara Penterjemah dan Penafsir al-Qur'an, 2009, 82.

Jurnal Pendidikan Agama Islam

Volume 02 Nomor 02 November 2014

Hal $360-387$
} 
Jadi kata al-samawat wa al-ardh wa ma baynahuma dalam surat tersebut memperkuat keterangan sebelumnya yang bersifat parsial, yakni apa-apa yang ada di belakang kita dan apa-apa yang ada diantara keduanya. Jadi secara umum atau keseluruhan, yakni al-samawat wa al-ardh wa baynahuma atau alam semesta adalah kepunyaan Allah SWT dan Dia yang mengaturnya sesuai dengan ketentuan-Nya.

Dari uraian yang diberikan diatas dapat ditegaskan bahwa al-Qur'an memakai kata al-samawat wa al-ardh wa ma baynahuma untuk istilah alam semesta. Kata ini mengacu kepada alam fisik dan non fisik (ghaib), seperti alam malaikat, jin, roh, dan lainnya. Dilihat dari sisi ini agaknya penafsiran alThaba Thabaiy tentang kata ini sulit diterima. Karena, menurutnya kata al-samawat wa al-ardh wa ma baynahuma adalah kumpulan alam fisik atau empiris saja (jumlat al-'alam al-mashhud). Hal ini bertentangan dengan pandangan para saintis, melalui perhitungan matematis mereka yang berkesimpulan bahwa selain alam yang didiami manusia, terdapat alam lain yang disebut shadow world atau alam ghaib dalam terminologi Islam, dengan hukum tersendiri yang berbeda sama sekali. ${ }^{6}$ Dalam ilmu pengetahuan kosmologi timbulnya banyak alam beserta hukum-hukumnya yang disebut sunnatullah ketika masa inflasi. Namun para saintis sampai hari ini belum dapat menentukan berapa jumlahnya secara eksak.

\section{Teori Terbentuknya Alam Semesta}

Alam semesta yang diketahui sekarang ini awal mulanya berasal dari gas yang berserakan secara teratur di

${ }^{6}$ A. Baiquni, Alam Ghaib Punya Hukum Sendiri, Pelita, (18 Maret 1991), 5. 
angkasa kemudian menjadi kabut (menjadi kumpulan kosmoskosmos). Dalam pengertian alam semesta mencakup tentang mikrokosmos dan makrokosmos. Mikrokosmos yaitu bendabenda yang berukuran kecil seperti, atom, sel, electron, dan benda-benda kecil lainnya. Adapun makrokosmos yaitu bendabenda yang berukuran besar, seperti bintang, planet, dan matahari. ${ }^{7}$

Teori yang dihasilkan oleh para ilmuwan dan pakar, tentang bagaimana terbentuknya alam semesta ada dua, yaitu:

1. Teori Keadaan Tetap (Steady-State Theory)

Teori ini berdasarkan prinsip kosmologi sempurna yang menyatakan bahwa alam semesta dimanapun dan bilamanapun selalu sama. Berdasarkan prinsip tersebut alam semesta terjadi pada suatu saat tertentu yang telah lalu dan segala sesuatu di alam semesta selalu tetap sama walaupun galaksi-galaksi saling bergerak menjauhi satu sama lain. Teori ini ditunjang oleh kenyataan bahwa galaksi baru mempunyai jumlah yang sebanding dengan galaksi lama. Dengan demikian teori ini secara ringkas menyatakan bahwa tiap-tiap galaksi terbentuk (lahir), tumbuh, menjadi tua dan akhirnya mati. Jadi, teori ini berangggapan bahwa alam semesta itu tak terhingga besarnya dan tak terhingga tuanya tanpa awal dan tanpa akhir. ${ }^{8}$

2. Teori Dentuman Besar (Big-Bang Theory)

Teori ini berlandaskan dari asumsi adanya massa yang sangat besar dan mempunyai massa jenis yang sangat besar, karena adanya reaksi inti kemudian meledak dengan

${ }^{7}$ Abdullah Aly, Ilmu Alamiah Dasar, (Jakarta: Bumi Aksara, 2000), 34.

8 Abdullah Aly, Ilmu Alamiah Dasar, 35

Jurnal Pendidikan Agama Islam

Volume 02 Nomor 02 November 2014

Hal $362-387$ 
hebat. Masssa tersebut kemudian mengembang dengan sangat cepat menjauhi pusat ledakan. ${ }^{9}$

Sebagaimana tercantum dalam al-Qur'an bahwasanya langit dan bumi keduanya dahulu adalah suatu yang padu dan kemudian dipisahkan:

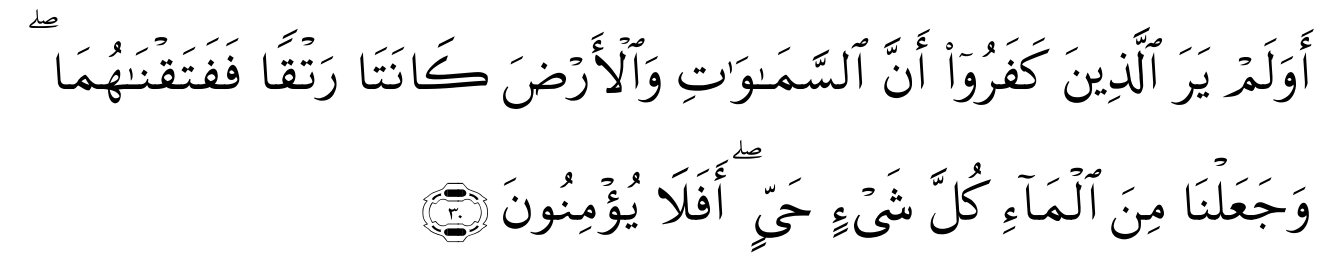

"Dan Apakah orang-orang yang kafir tidak mengetahui bahwasanya langit dan bumi itu keduanya dahulu adalah suatu yang padu, kemudian Kami pisahkan antara keduanya. dan dari air Kami jadikan segala sesuatu yang hidup. Maka mengapakah mereka tiada juga beriman?" (Q.S. al-Anbiya': 30) ${ }^{10}$

Menurut teori ini ada beberapa massa yang penting selama terjadinya alam semesta, yaitu:

a. Massa batas dinding Planck, yaitu massa pada saat alam semesta berumur 10-43 detik berdasarkan hasil perhitungan Planck.

b. Massa Jiffy, yaitu massa pada saat alam semesta berumur $10^{-23}$ detik, dengan jari-jari alam semesta 10-13 cm dengan kecepatannya $10^{-55}$ kerapatan air.

c. Massa Quark, yaitu massa pada saat alam semesta berumur $10^{-4}$ detik. Pada masa ini partikel-partikel saling bertumpang tindih dan tidak berstruktur serta diikuti dengan terbentuknya hadron yang mempunyai kerapatan $10^{9}$ ton tiap sentimeter kubik.

9 Mawardi, Ilmu Alamiah Dasar, Ilmu Sosial Dasar, Ilmu Budaya Dasar, (Bandung: Pustaka Setia, 2004), 27.

10 Departemen Agama RI, Al-Qur'an.... 125. 
d. Massa pembentukan Lipton, yaitu massa pada saat alam semesta berumur setelah $10^{-4}$ detik.

e. Massa Radiasi, yaitu massa alam semesta berumur 1 detik sampai satu juta kemudian pada saat terbentuknya fusi hidrogen menjadi helium mempunyai suhu $10^{9}$ derajat Kelvin. Pada saat usia alam semesta berumur $10^{5}$ sampai $10^{6}$ tahun mempunyai suhu 3000 derajat Kelvin. ${ }^{11}$

3. Teori Nebula

Teori Kabut atau disebut juga Teori Nebula. Teori Nebula pertama kali dikemukakan oleh Emanuel Swedenborg (1688-1772) tahun 1734 dan disempurnakan oleh Immanuel Kant (1724-1804) pada tahun 1775.

Teori Kabut (Nebula) menceritakan kejadian tersebut dalam 3 (tiga ) tahap: ${ }^{12}$

a. Matahari dan planet-planet lainnya masih berbentuk gas, kabut yang begitu pekat dan besar

b. Kabut tersebut berputar dan berpilin dengan kuat, dimana pemadatan terjadi di pusat lingkaran yang kemudian membentuk matahari. Pada saat yang bersamaan materi lainpun terbentuk menjadi massa yang lebih kecil dari matahari yang disebut sebagai planet, bergerak mengelilingi matahari.

c. Materi-materi tersebut tumbuh makin besar dan terus melakukan gerakan secara teratur mengelilingi matahari dalam satu orbit yang tetap dan membentuk susunan keluarga matahari.

${ }^{11}$ Abdullah Aly, Ilmu Alamiah.........., 35.

12 Abdullah Aly, Ilmu Alamiah..........., 34.

Jurnal Pendidikan Agama Islam

Volume 02 Nomor 02 November 2014

Hal $364-387$ 


\section{Kedudukan Alam Semesta}

Apabila merenungi surat al-Fatihah sebagai ummul kitab, kita akan menemukan review yang luar biasa dari semua ayat Allah swt yang tercatat dalam kitab suci al-Qur'an. lafadh bismillahi al-rahmani al-rahim adalah awal yang menekad bulatkan semua niat manusia yang beriman kepada Allah swt dalam bertindak, berperilaku, berpikir, dan berkarya nyata sehingga semua aktivitas dan karsa manusia bernilai kepada Allah swt dan tidak ada yang sia-sia secara duniawi maupun ukhrawi. ${ }^{13}$

Allah swt sebagai pencipta atau khaliq, pemilik dan kasih sayang untuk segenap makhluk-Nya. Alam ini tercipta sebagai bukti dari kasih sayang Allah swt untuk manusia. Apabila meresapi ayat yang berbunyi maliki yawmi al-din kita tersadarkan sepenuhnya bahwa semua alam ini adalah hambaNya yang secara mutlak harus tunduk pada hukum-hukum Allah swt. Allah swt adalah raja untuk semua masa, baik masa lalu, masa kini maupun masa yang akan datang. Masa yang belum dirasakan oleh semua makhluk-Nya karena belum dilahirkan atau karena telah menemui ajal adalah masa yang ada di atas kehendak Allah swt.

Alam tunduk mutlak pada hukum-hukum Allah swt. Semua alam yang berjalan sesuai dengan hukumnya menjadi subjek sekaligus objek pendidikan dan pembelajaran. Bagaimana matahari konsisten untuk terbit dan terbenam sesuai dengan hukumnya, bagaimana air, api, angin, daratan lautan, gunung-gunung, hutan dan pepohonan, bumi yang berputar sangat kencang sehingga manusia bagaikan sedang berjalan di atas hamparan tikar, dan demikian selanjutnya.

${ }^{13}$ Hasan Basri, Filsafat Pendidikan Islam (Bandung: Pustaka Setia, 2009), 21. 
Alam adalah guru manusia, kita semua wajib belajar dari sikap alam semesta yang tunduk mutlak pada hukumhukum yang telah ditetapkan Allah swt. Tidak terbayangkan oleh kita semua manakala alam berperilaku di luar hukumhukum Allah swt, alam melanggar sunnahnya. Gunung meletus menyemburkan api, matahari terbit dan turun ke bumi, bintang-bintang berjatuhan pohon-pohon tumbang, lautan meluap, ombak menghantam, terjadi badai, dan bumi berhenti berputar. ${ }^{14}$

Demikian pula, manusia yang tidak mau belajar dari konsistensi kehidupan alam. Sifatnya berubah bagaikan binatang, saling menipu, saling membunuh, saling memfitnah, korup, pezina, dan sebagainya. Rusaknya kehidupan alam disebabkan oleh perilaku manusia yang tidak mau belajar dari alam semesta yang indah ini. Misalnya, kasus penebangan hutan liar mengakibatkan hutan gundul, erosi, kebanjiran, bencana, kelaparan, kehancuran, dan kebiadaban di antara manusia.

Alam semesta ini dapat dijadikan guru yang bijaksana, ombak lautan yang dapat menjadi energi bagi para peselancar, angin dimanfaatkan untuk terjun payung, air deras yang dibendung untuk energi pembangkit listrik, dan banyak manfaat yang dengan mudah semakin meningkatkan taraf hidup manusia. Belajar dari alam semesta adalah tujuan hidup manusia dan secara filosofis kedudukan alam semesta bagaikan guru dengan muridnya, pendidikan dengan anak didik, bahkan alam semesta bagaikan literatur yang amat luas dan kaya dengan informasi yang aktual. Alam mempertontonkan karyanya yang dinamis kepada manusia yang berniat belajar seumur hidup.

${ }^{14}$ Hasan Basri, Filsafat Pendidikan Islam, 22.

Jurnal Pendidikan Agama Islam

Volume 02 Nomor 02 November 2014

Hal 366 - 387 
Allah swt berfirman dalam surat al-Mulk ayat 3:

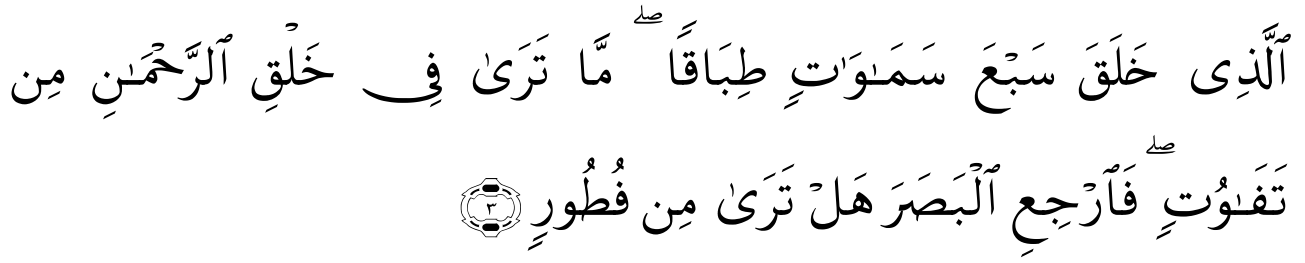

"yang telah menciptakan tujuh langit berlapis-lapis. kamu sekali-kali tidak melihat pada ciptaan Tuhan yang Maha Pemurah sesuatu yang tidak seimbang. Maka lihatlah berulang-ulang, Adakah kamu Lihat sesuatu yang tidak seimbang?" (Q.S. al-Mulk: 3) ${ }^{15}$

Ayat di atas menegaskan karya Tuhan yang indah dan sempurna. Alam semesta ini sebagaimana tujuh lapis langit, dan planet-planet, diciptakan Tuhan dengan hukumnya yang pasti. Teori equilibrium atau keseimbangan telah berlaku pada semua alam ini.

Adakah kita semua telah belajar tentang tujuh langit yang bertingkat-tingkat? Sepantasnya kita sebagai muslim merasa malu, sebab setiap hari membaca al-Qur'an bisa jadi ayat tersebut sering kita baca, tetapi mengapa kita tidak pernah mengetahui rumus tentang keajegan planet, tentang langit yang berlapis dan bertingkat, sebagaimana kita katakan bahwa di atas langit ada langit. Betapa al-Qur'an menjadi sumber penting bagi pengembangan ilmu pengetahuan alam, yang secara filosofis, ayat-ayat tentang penciptaan langit merupakan hakikat dari pendidikan Islam tentang bendabenda angkasa raya.

Dalam surat al-Furqan ayat 25, Allah swt menegaskan kembali:

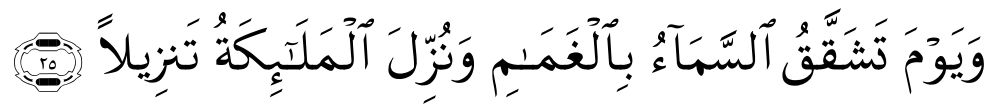

15 Departemen Agama RI, Al-Qur'an.........., 76. 
"Dan (ingatlah) hari (ketika) langit pecah belah mengeluarkan kabut putih dan diturunkanlah Malaikat bergelombang-gelombang" (Q.S. al-Furqan: 25). ${ }^{16}$

Ada dua hal yang sukar dipahami dari ayat dia atas, yaitu: 1. Langit yang pecah belah mengeluarkan kabut putih; 2 . Diturunkannya malaikat secara bergelombang. Siapa yang memiliki kemampuan menafsirkan dua hal diatas. Apabila sebagai muslim tidak mengerti, betapa malu kita semua, padahal alam semesta ini diciptakan bagi orang-orang yang berpikir dan memiliki kemampuan menjaga dan memeliharanya.

Apakah makna langit yang pecah mengeluarkan kabut putih adalah asap yang putih berpisah dengan asap hitam, apakah malaikat yang turun bergelombang adalah hujan deras yang merupakan rahmat Allah swt. Kita hanya mengira-ngira karena untuk menjawab semua itu diperlukan pengetahuan. Itu tidak akan terjawab dengan ilmu fiqh ataupun ilmu kalam, melainkan membutuhkan sains yang mengajarkan teori-teori tentang alam semesta, perbintangan dan planet-planet karya Allah swt yang luar biasa.

Kembali kepada surat al-Fatihah, kata alhamdulillah adalah kata pujian dan syukur kita yang amat luar biasa sebab hanya kepada Allah swt kita memuji dan hanya kepada Allah swt kita berterima kasih atas segala kasih sayang-Nya. Rabbul 'alamin, inilah ayat yang menegaskan bahwa Allah swt adalah pencipta, Allah adalah pendidik, dan pemelihara. al-'alamin berasal dari kata 'alama atau 'ilmu, sehingga Allah swt itu pendidik, maka mutlak pemilik semua ilmu.

Para pendidik harus berilmu dan menguasai ilmunya dengan baik dan benar, para pendidik harus memberikan

16 Departemen Agama RI, Al-Qur'an 439.

Jurnal Pendidikan Agama Islam Volume 02 Nomor 02 November 2014

Hal $368-387$ 
contoh dan suri teladan kepada anak didiknya agar ilmu yang disampaikan diterima dengan terbuka dan bermanfaat bagi kehidupan anak didiknya di masa depan.

Kata rabba, yarubbu, tarbiyatan, rabba, yarubbu, rabba. Bermakna mendidik, mengasuh, membimbing, dan memimpin. Tarbiyah artinya pendidikan maka jika dikaitkan dengan fakultas tarbiyah adalah fakultas yang seharusnya benar-benar berpijak dari cara-cara Allah swt mengajar semua makhlukNya. Fakultas tarbiyah wajib belajar kepada alam semesta ini agar pendidikan yang diarahkan kepada anak didik adalah pendidikan yang bertujuan membentuk sikap konsisten atau istiqamah dalam berpedoman pada hukum-hukum yang telah digariskan Tuhan, sebagaimana alam tunduk mutlak pada hukumnya yang berlaku menurut sunnatullah.

Sebagai rabbul 'alamin, Allah swt adalah yang mengurus, mengatur, memperbaiki proses penciptaan alam semesta ini, dan menjadikannya bertumbuh kembang secara dinamis hingga tercapai tujuan penciptaannya. ${ }^{17}$ Kedudukan alam semesta dalam perspektif filsafat pendidikan Islam adalah sebagai guru yang mengajar kepada manusia untuk bertindak sesuai dengan hukum-hukum yang telah digariskan Tuhan. Fungsi konkret alam semesta adalah fungsi rubbubiyah yang dicitrakan Allah swt kepada manusia sehingga alam ini akan marah manakala manusia bertindak serakah dan tidak bertanggung jawab.

Manusia dapat mengambil pelajaran dari alam semesta ini. Manusia harus memanfaatkan akalnya untuk berpikir tentang pemberdayaan alam bagi manusia. Akal yang dimiliki manusia merupakan kecakapan untuk menciptakan alat-alat kerja bagi dirinya dan secara bebas mengubah-ubah

17 Muhaimin, Paradigma Pendidikan Islam: Upaya Mengefektifkan Pendidikan Agama Islam di Sekolah (Bandung: Rosdakarya, 2001), 27. 
pembuatan alat-alat kerja itu. Akal mencakapkan manusia untuk menyadarkan diri akan kepentingan individu-individu. Akan tetapi, akal tidak dapat dipakai untuk menyelami hakikat yang sebenarnya dan segala kenyataan. Sebab, akal adalah hasil perkembangan, yaitu perkembangan dalam rangka proses hidup. Akal itu timbul karena penyesuaian manusia. Dengan akalnya, manusia dapat menyesuaikan diri dengan dunia sekitarnya. Oleh karena itu, akal memiliki fungsi praktis. Itulah sebabnya, akal tidak dapat menyelami hakikat yang sebenarnya dari segala kenyataan. Akal hanya amat berguna bagi pemikiran ilmu fisika dan mekanika, tetapi akal tidak berguna bagi penyelaman ke dalam hakikat sesuatu. ${ }^{18}$

\section{E. Tujuan Memahami Alam}

Dalam al-Qur'an terdapat penjelasan tentang alam semesta dan fenomena-fenomenanya secara eksplisit tidak kurang dari 750 ayat. ${ }^{19}$ Pada umumnya ayat-ayat ini memerintahkan manusia untuk memperhatikan, mempelajari, dan meneliti alam semesta. Perintah ini tidak berarti al-Qur'an adalah ensiklopedi kealaman. Rujukan ini bertujuan mengantarkan manusia agar mereka menyadari bahwa di balik "tirai" alam semesta ini ada dzat yang maha kuasa dan maha esa, yakni Allah swt.

Ajakan al-Qur'an di atas dialamatkan kepada seluruh manusia tanpa membedakan warna kulit, profesi, waktu dan tempat. ${ }^{20}$ Fakta ini dapat dijadikan bukti sebagai salah satu

\footnotetext{
18 Atang Abdul Hakim, Metodologi Studi Islam (Bandung: Rosdakarya, 2007), 345.

19 Tanthawi Jauhari, al-Jawahir fi al-Tafsir al-Qur'an, Jilid I (Beirut: Dar al-Fikr, $\mathrm{tt}), 3$.

20 Lihat: Q.S. al-An-'am: 19 dan 20; dan Q.S. al-A'raf: 158. al-Zaqani menyebut keumuman al-Qur'an pada seluruh manusia adalah sebagai keistimewaan

Jurnal Pendidikan Agama Islam

Volume 02 Nomor 02 November 2014

Hal $370-387$
} 
keistimewaan al-Qur'an. Dengan demikian setiap pribadi manusia merasa bahwa khitab al-Qur'an dihadapkan kepada diri mereka sendiri. Hal ini sejalan dengan pernyataan alQur'an sebagai petunjuk manusia. Jika tidak demikian tentu Islam telah menjadi agama elit yang hanya dapat dipahami oleh golongan atau kelompok tertentu saja. Agaknya ada benarnya kritik yang dilontarkan ibn Taimiyah terhadap kaum filosof Islam yang mengkalim bahwa agama dinyatakan dalam lambang-lambang dan rumus-rumus, untuk memudahkan pemahaman bagi kaum awam yang merupakan bagian terbesar umat manusia, sedangkan hakikatnya hanya dipahami oleh kaum filosof saja. Pemahaman semacam ini, menurut diagnose juris pasca mongol ini, telah menempatkan nabi berdusta untuk kepentingan manusia. ${ }^{21}$

Dorongan al-Qur'an untuk mempelajari dan meneliti kitab alam dengan memperkuat keyakinan bahwa Tuhan memang maha kuasa sebagai dijelaskan oleh kitab wahyu. ${ }^{22}$ Ajakan tersebut disertai dengan menunjukkan fakta-fakta yang dapat dilihat oleh manusia di alam raya ini.

Dengan demikian perintah harus pandai membaca bagi umat Islam bukan kitab wahyu, tetapi juga kitab alam. Dari hasil meneliti kitab alam ini akan ditemukam keserasian dan kecocokannya dengan kitab wahyu. Karena kedua kitab ini memang dirancang untuk tujuan demikian oleh tangan yang sama dengan sumber yang sama, yakni Allah swt. Dasar ini

hidayah al-Qur'an. Lihat bukunya: Manahi al-'Urfan fi 'Ulum al-Qur'an, Jilid II (Beirut: Dar al-Fikr, 1999), 124.

21 Taqi al-Din Abi al-Abbas Ahmad Ibn Taimiyyat al-Harrani, Kitab al-Radd 'ala al-Mant\}iqiyyin (Makkah: Dar al-Baz li al-Nasyr wa al-Tawzwi, tt), 124.

22 Di antara ayat -ayat yang mendorong untuk memperhatikan dan mempelajari alam semesta adalah Q.S. Yunus: 101, Q.S. al-Ghasyiyat: 17-22 dan 164, Q.S. Ali 'Imran: 190, Q.S. al-Zariyat: 20-21, Q.S. al-Jasiyyat: 3-4, Q.S. alBaqarah: 22 dan 164 dan Q.s. Qaf: 9-11. 
juga yang mendorong Maurice Bucaille, ahli bedah Perancis melakukan penelitian atas kasus kematian Raja Firaun yang hidup pada zaman nabi Musa. Rencananya ini terlaksana pada bulan Juni 1975 setelah mendapat izin dari penguasa tinggi Mesir. Berdasarkan informasi al-Qur'an, Firaun meninggal karena tenggelam di laut, sementara jasadnya selamat.

Dari hasil penyelidikan ini, Bucaille menyimpulkan sebagai berikut: ${ }^{23}$

"Alangkah agungnya contoh-contoh yang diberikan oleh ayat-ayat al-Qur'an tentang tubuh Firaun yang sekarang berada di ruang mummi di Museum Mesir di kota Kairo. Penyelidikan dan penemjuan-penemuan modern telah menunjukkan kebenaran al-Qur'an."

Kasus di atas merupakan contoh atas kebenaran alQur'an yang diakui oleh penemuan modern. Sesuai dengan janji Allah bahwa dia telah menyelamatkan jasad Fir'aun sehingga dapat disaksikan sampai hari ini. Sedangkan seluruh jasad para pengikutnya lenyap tenggelam tanpa diketahui lagi. Peristiwa ini merupakan pelajaran bagi generasi sesudahnya supaya mereka beriman kepada Allah swt setelah mereka membuktikan kebenaran janji-Nya.

${ }^{23}$ Hasil pembedahan Maurice Bucaille menunjukkan bahwa Fir'aun meninggal bukan karena garam laut, kendatipun sekujur tubuhnya penuh dengan garam laut, namun dia meninggal karena shok tenggelam di laut. Hasil pembedahan ini sekiranya benar tidak bertentangan dengan redaksi al-Qur'an, yang pada hakikatnya terjadinya shok tersebut disebabkan tenggelamnya juga. Hal inilah yang agaknya menyebabkan jasad Firaun utuh begitu lama. Peristiwa ini merupakan salah satu tanda kemahakuasaan Allah swt yang terkadang sulit dicernakan oleh daya nalar manusia. Ketika Maurice Bucaille memeriksa tubuh Firaun memang terdapat kerusakan-kerusakan di beberapa bagian tubuhnya, akan tetapi kerusakan ini disebabkan oleh cara memeliharanya sejak ia diketemukan. Lihat: Koesmawan, al-Qur'an sebagai Konsep yang Sangat Sentral dalam Pengembangan Ilmu Pengetahuan (Jakarta: IKIP Muhammadiyah, 1990), 7. 
Membaca ayat-ayat kawniyyat bagi orang-orang yang beriman non-ilmuwan akan menimbulkan pikiran dan imajinasi tentang langit pada malam hari dengan bintangbintang bertaburan, bulan yang bercahaya, laut yang dipenuhi ikan berbagai jenis dan bumi yang ditumbuhi berbagai tumbuhan tyang hidup diatasnya beraneka makhluk. Lain halnya saintis kosmolog dan astronom, mereka akan berpikir betapa maha kuasanya Allah swt menciptakan alam yang sedemikian luasnya. Seluruh jagat raya berada dalam sebuah struktur yang kokoh dan terpadu tanpa cacat. Ia bekerja menurut hukumnya sendiri yang bersumber dari Allah swt. Kesemuanya itu membuat manusia baik non-ilmuwan maupun ilmuwan akan terpesona dan takjub sehingga membangunkan kesadaran mereka atas kebesaran dan keperkasaan Allah dan menginsyafi pula atas kekecilan dan kelemahan manusia sebagai hamba-Nya.

Membaca ayat-ayat kawniyyat tanpa memiliki ilmu pengetahuan ilmiah (sains) sebagai ilmu bantu akan sulit memahaminya dengan sempurna. Nampaknya pendapat Baiquni dapat dibenarkan ketika ia menafsirkan al-Qur'an surat Yunus ayat 101 dan surat al-Ghashiyat: 17-20.

1. Surat Yunus ayat 101:

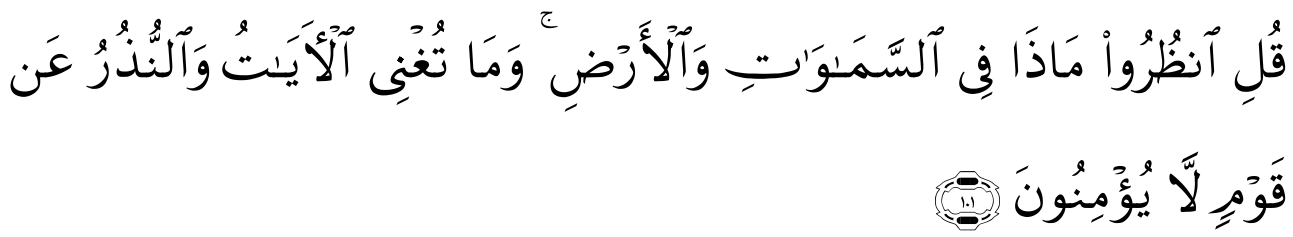

Katakanlah: "Perhatikanlah apa yaag ada di langit dan di bumi. tidaklah bermanfaat tanda kekuasaan Allah dan Rasul-rasul yang memberi peringatan bagi orang-orang yang tidak beriman" (Q.S. Yunus: 101). ${ }^{24}$ 
2. Surat al-Ghashiyat ayat 17-20:

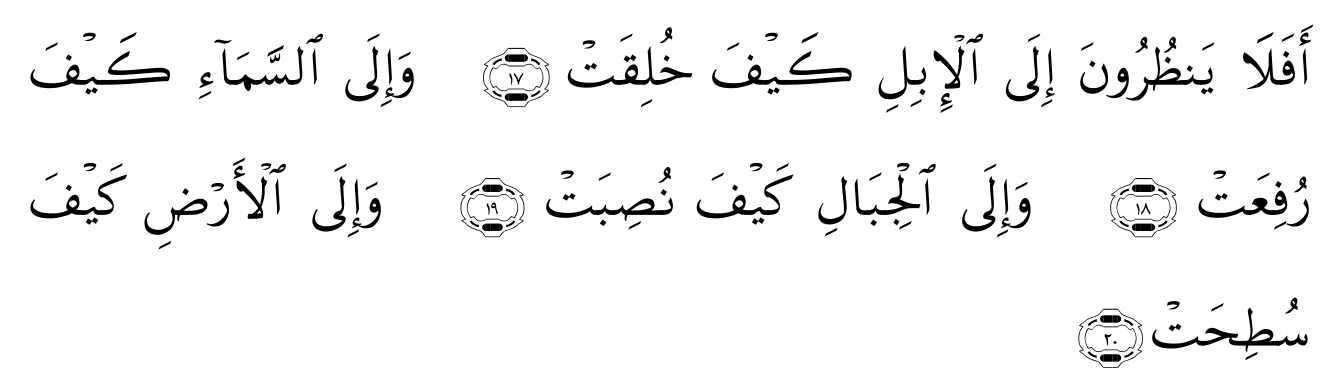

Maka Apakah mereka tidak memperhatikan unta bagaimana Dia diciptakan. dan langit, bagaimana ia ditinggikan?. Dan gunung-gunung bagaimana ia ditegakkan? Dan bumi bagaimana ia dihamparkan? (Q.S. al-Ghashiyat: $17-20) .{ }^{25}$

Menurutnya kata unzhuru dan yanzhurun tidak dapat diartikan dengan melihat saja, melainkan melihat sengan memperhatikan, karena dengan melihat saja tidak akan menjawab pertanyaan kunci: bagaimana unta dijadikan atau diciptakan, bagaimana langit ditinggikan, bagaimana gununggunung ditegakkan dan bagaimana bumi dibentangkan. ${ }^{26}$

Keyakinan manusia kepada Allah swt akan bertambah jika mereka mengamati jenis binatang dan tumbuhan yang sangat banyak. Al-Qur'an memang hanya membicarakan beberapa jenis saja, namun ini tidak berarti membatasi bagi manusia menelitinya. Artinya, al-Qur'an sebagai pengantar bagi manusia untuk mengembangkannya lebih jauh. Sebagai contoh, Allah swt mengajak manusia untuk mengamati unta bagaimana ia diciptakan. Ini bukan berarti bahwa Allah swt membatasi obyek penelitian manusia pada jenis unta saja, ${ }^{27}$ melainkan mereka bisa memilih salah satu dari sekitar satu

25 Departemen Agama RI, Al-Qur'an 564.

${ }^{26}$ Achmad Baiquni, al-Qur'an dan Ilmu Fisika dalam Perspektif Pengembangan Tafsir al-Qur'an (Jakarta: UIN Syarif Hidayatullah, 2009), 3.

27 Lihat: Q.S. al-Gha>syiyat: 17.

Jurnal Pendidikan Agama Islam

Volume 02 Nomor 02 November 2014

Hal $374-387$ 
juta jenis hewan termasuk unta, yang terbagi atas 800.000 jenis serangga, 21.000 jenis ikan, 86.000 jenis burung, 4.000 jenis mamalia dan lainnya. Demikian penyebutan ketimun, bawang putih, kacang-kacangan ${ }^{28}$, zaitun, kurma, anggur ${ }^{29}$ dan lainnya tidak dimaksudkan untuk membatasi obyek kajian manusia pada tumbuh-tumbuhan ini saja, tetapi manusia bisa memilih salah satu dari 35.000 tumbuh-tumbuhan yang kini sudah ditemukan dan di daftar. Mulai dari memilih tumbuhtumbuhan terkecil yang bernama diatom sampai pada pohon sequia yang terbesar di dunia ini. ${ }^{30}$

\section{F. Cara-cara Memahami Alam}

Al-Qur'an dalam berbagai ayatnya senantiasa mendesak manusia untuk membaca dan memahami "kitab alam" sebagai pertanda adanya Tuhan Pencipta Alam dan hukum alam yang mengatur perjalanan alam. Pelaksanaan perintah ini akan dapat membantu manusia mendekatkan diri kepada Allah swt.

Untuk mencapai hal diatas, al-Qur'an juga membicarakan prinsip-prinsip tentang cara-cara memahami alam semesta. Dalam beberapa tempat al-Qur'an menunjukkan bahwa salah satu cara memahami alam raya ini dapat dilakukan lewat indera penglihatan, pendengaran, perasa, pencium, dan peraba. ${ }^{31}$ Semua alat utama ini dapat membantu manusia untuk melakukan pengamatan dan eksperimen.

\footnotetext{
${ }^{28}$ Lihat: Q.S. al-Baqarah: 61.

${ }^{29}$ Lihat: Q.S. al-Nahl: 11 dan Q.S. al-An'am: 99.

30 Marwah Daud Ibrahim, Etika, Sinergi Ilmu dan Teknologi Masa Depan ( Jakarta: Rosda, 1999), 66.

${ }^{31}$ Mahdi Ghulsya, Filsafat Sains Menurut al-Qur'an, ter. Agus Effendi (Bandung: Mizan, 1998), 83.
} 
Perlunya mengadakan pengamatan juga diragakan al-Qur'an dalam beberapa kasus, diantaranya:

1. Surat al-Maidah: 5

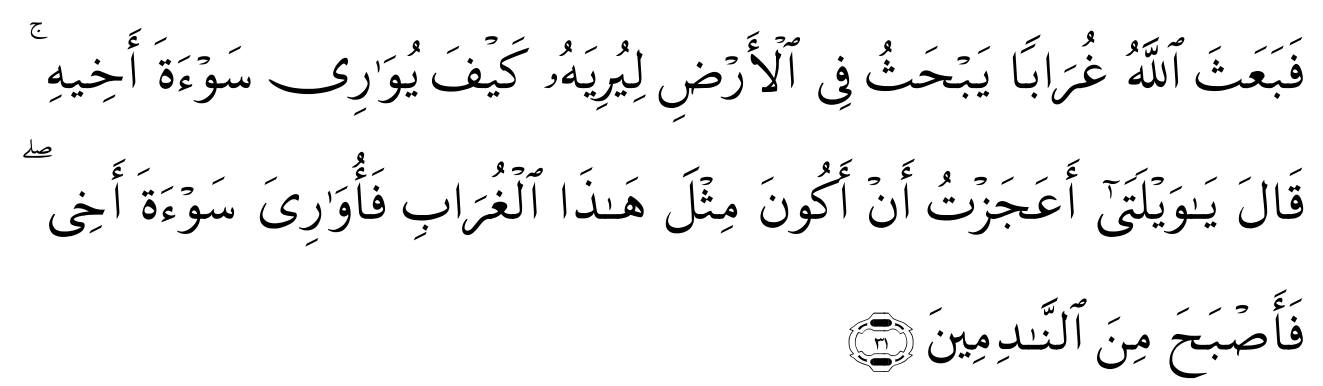

"Kemudian Allah menyuruh seekor burung gagak menggali-gali di bumi untuk memperlihatkan kepadanya (Qabil) bagaimana seharusnya menguburkan mayat saudaranya. ${ }^{32}$ berkata Qabil: "Aduhai celaka Aku, mengapa aku tidak mampu berbuat seperti burung gagak ini, lalu aku dapat menguburkan mayat saudaraku ini?" karena itu jadilah Dia seorang diantara orang-orang yang menyesal" (Q.S. al-Maidah: 5). ${ }^{33}$

Dalam surat tersebut, Allah swt memberi pengajaran kepada Qabil, bagaimana seharusnya ia menguburkan mayat saudaranya. Pelajaran ini ditayangkan Allah swt lewat peranan seekor burung gagak yang menggali-gali tanah.

2. Surat al-Baqarah: 260

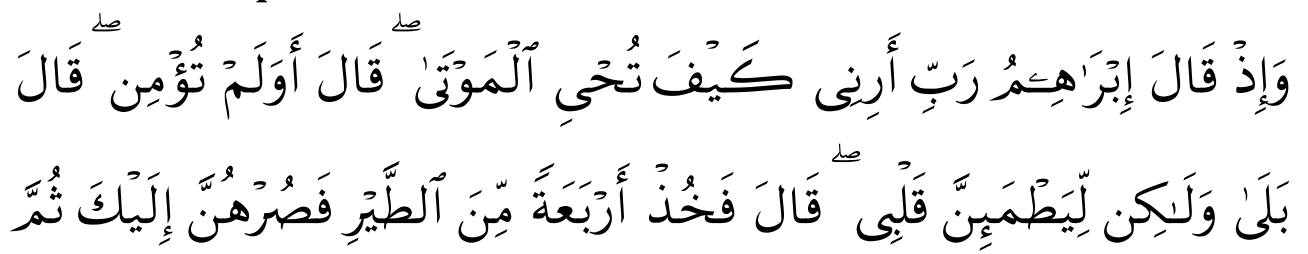

32 Dipahami dari ayat ini bahwa manusia banyak pula mengambil pelajaran dari alam dan jangan segan-segan mengambil pelajaran dari yang lebih rendah tingkatan pengetahuannya.

33 Departemen Agama RI, Al-Qur'an 285.

Jurnal Pendidikan Agama Islam

Volume 02 Nomor 02 November 2014

Hal $376-387$ 


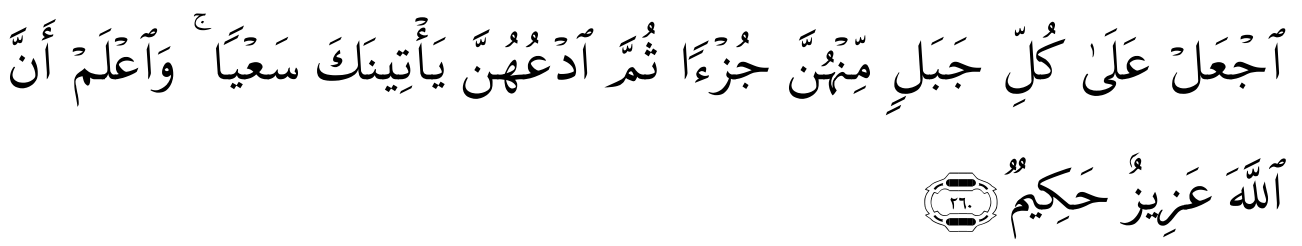

"Dan (ingatlah) ketika Ibrahim berkata: "Ya Tuhanku, perlihatkanlah kepadaku bagaimana Engkau menghidupkan orang-orang mati." Allah berfirman: "Belum yakinkah kamu ?" Ibrahim menjawab: "Aku telah meyakinkannya, akan tetapi agar hatiku tetap mantap (dengan imanku) Allah berfirman: "(Kalau demikian) ambillah empat ekor burung, lalu cincanglah ${ }^{34}$ semuanya olehmu. (Allah berfirman): "Lalu letakkan diatas tiap-tiap satu bukit satu bagian dari bagian-bagian itu, kemudian panggillah mereka, niscaya mereka datang kepadamu dengan segera." dan ketahuilah bahwa Allah Maha Perkasa lagi Maha Bijaksana."35

Dalam surat tersebut, Allah swt memberi petunjuk kepada Ibrahim as bagaimana dia menghidupkan yang mati. Petunjuk ini disampaikan Allah swt kepadanya dengan perantaraan empat ekor burung yang dipotong-

\footnotetext{
${ }^{34}$ Pendapat diatas adalah menurut At-Thabari dan Ibnu Katsir, sedang menurut Abu Muslim Al Ashfahani pengertian ayat diatas bahwa Allah memberi penjelasan kepada Nabi Ibrahim a.s. tentang cara Dia menghidupkan orangorang yang mati. Disuruh-Nya Nabi Ibrahim a.s. mengambil empat ekor burung lalu memeliharanya dan menjinakkannya hingga burung itu dapat datang seketika, bilamana dipanggil. Kemudian, burung-burung yang sudah pandai itu, diletakkan di atas tiap-tiap bukit seekor, lalu burung-burung itu dipanggil dengan satu tepukan/seruan, niscaya burung-burung itu akan datang dengan segera, walaupun tempatnya terpisah-pisah dan berjauhan. Maka demikian pula Allah menghidupkan orang-orang yang mati yang tersebar di mana-mana, dengan satu kalimat cipta hiduplah kamu semua pastilah mereka itu hidup kembali. Jadi menurut Abu Muslim sighat amr (bentuk kata perintah) dalam ayat ini, pengertiannya khabar (bentuk berita) sebagai cara penjelasan. Pendapat beliau ini dianut pula oleh Ar Razy dan Rasyid Ridha.
}

35 Departemen Agama RI, Al-Qur'an 96.

Jurnal Pendidikan Agama Islam Volume 02 Nomor 02 November 2014 Hal $377-387$ 
potong, kemudian dibagi-bagi dan masing-masing bagiannya diletakkan di beberapa bukit yang berjauhan. Setelah itu burung-burung tersebut dipanggil Ibrahim as, lantas mereka datang segera.

Dengan demikian tidak perlu disangsikan lagi bahwa al-Qur'an memandang pengamatan indera sebagai saluran utama dalam memahami alam semesta. Namun dalam ayat-ayat lain, ditegaskan pula bahwa saluran ini belumlah cukup dan dibutuhkan saluran lain, yakni penalaran atau akal. Saluran ini sangat dibutuhkan untuk menjawab pertanyaan yang tidak dapat diselesaikan melalui pengamatan, seperti menjawab kata kunci yang terdapat dalam surat al-Ghasyiyah: 17-20, yaitu:

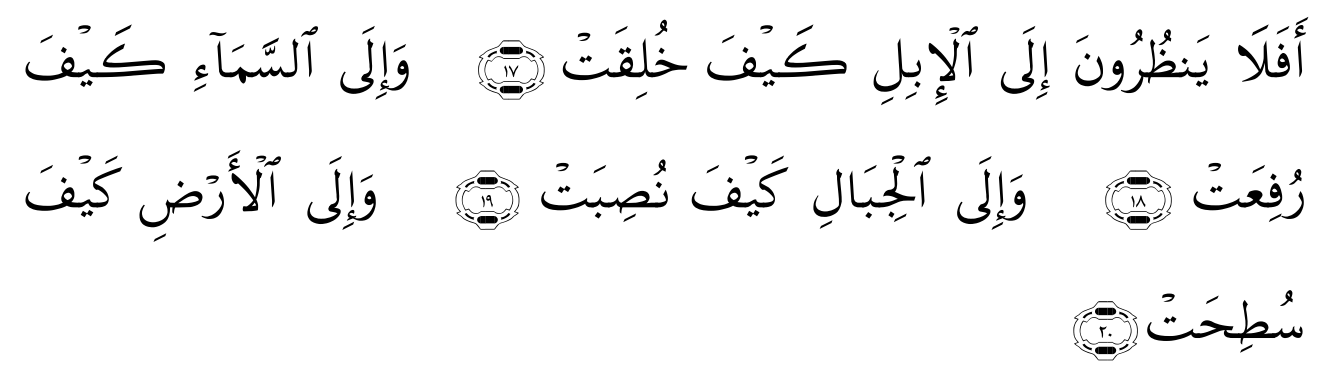

"Maka apakah mereka tidak memperhatikan unta bagaimana dia diciptakan. Dan langit, bagaimana ia ditinggika?. Dan gunung-gunung bagaimana ia ditegakkan?. Dan bumi bagaimana ia dihamparkan? (Q.S. al-Ghashiyah 17-20). ${ }^{36}$

Dari ayat-ayat di atas jelaslah kiranya bahwa daya nalar sangat dibutuhkan dalam memahami alam semesta disamping pengamatan indera. Andaikan hanya bersandar pada pengamatan indera semata, manusia tidak akan mampu menafsirkan proses alamiah dan menemukan hubungan-hubungan di antara kejadian di jagat raya ini.

36 Departemen Agama RI, Al-Qur'an. 124.

Jurnal Pendidikan Agama Islam Volume 02 Nomor 02 November 2014

Hal $378-387$ 
Karena daya nalarlah yang mampu menguak tabir, mengungkapkan misteri dan menghubung-hubungkan tanda-tanda atau sinyal-sinyal yang dipancarkan alam yang teramati lewat pengamatan.

Al-Qur'an juga menunjukkan bahwa' masih ada cara lain disamping cara pengamatan dan daya nalar, yakni melalui wahyu dan ilham. Akan tetapi cara ini tidaklah semua orang dapat menikmatinya melainkan hanya orangorang pilihan Allah swt semata. Wahyu hanya dianugerahkan Allah kepada para rasul dan nabi, sedangkan manusia biasa hanya dapat memperoleh ilham. ${ }^{37}$ Namun antara keduanya terdapat perbedaan, perbedaannya menurut Harun Nasution ialah ilham terjadinya di dahului ide dan barulah kemudian ide itu diungkapkan dalam kata-kata. Sementara wahyu yang terjadi pada diri nabi tidak ada ide sebelumnya. Nabi mendengar suara yang jelas tanpa ada ide yang mendahului ataupun bersamaan datangnya dengan kata yang diucapkan. ${ }^{38}$

Melalui uraian di atas dapat disimpulkan bahwa menurut al-Quran cara yang digunakan untuk memahami alam semesta ialah pengamatan, daya nalar dan wahyu atau ilham. Ilmu pengetahuan alam atau sains natural juga mendasarkan kegiatannya kepada beberapa unsur. Unsur penting yang pertama, ialah observasi atau pengamatan. Penekanan kepada metode ini sudah seharusnya dalam ilmu ini. Untuk mengetahui proses-proses kealaman orang tidak dapat melakukan dengan pengkhayalan atau berspekulasi. Jika ilmu berdasarkan khayalan atau

37 Departemen Agama RI, Al-Qur'an 95.

${ }^{38}$ Harun Nasution, Akal dan Wahyu dalam Islam (Jakarta: Universitas Indonesia, 1993), 23. 
berspekulasi kebenarannya akan diragukan. Pada sisi lain ia merupakan medan dari ilmu pengetahuan. Mencampurkan pembidangan ini tanpa membedakan dimana sistemnya harus berlaku akan melahirkan kerancuan. Agaknya diagnosa A. Rahman Djay dapat dibenarkan ketika ia mengatakan bahwa penyebab kemunduran umat Islam karena orang Islam tidak menempatkan porsi ilmu sesuai dengan bidangnya, seperti fenomena alam tidak ditempatkan pada bidang kajian sains dan teknologi.

Metode observasi di atas tidak bertentangan dengan petunjuk al-Qur'an sebagaimana tayangan sebelumnya. Bahkan kegiatan ini memperkuat apa yang dianjurkan alQur'an. Karena pelaksanaan metode ini dalam sains telah dilengkapi dengan alat-alat sarana observasi. Keakuratan datanya tergantung pada tingkat kecanggihan alat-alat ini.

Pengukuran adalah unsur terpenting yang kedua dalam kegiatan sains natural. Kegiatan ini juga sejalan dengan pernyataan al-Qur'an karena Allah swt menciptakan segala sesuatu di alam raya ini dilengkapiNya dengan ukuran atau peraturan tertentu. Ungkapan qadr dalam al-Qur'an berarti ukuran. ${ }^{39}$ Jadi setiap benda di alam ini telah ditentukan potensi-potensinya beserta hukum-hukum tingkah lakunya. Dengan arti Allah swt memberikan sifat-sifat tertentu kepada setiap benda, maka benda tersebut berjalan sesuai dengan sunnatullah atau

\footnotetext{
39 Qadr dalam al-Qur'an salah satu artinya ukuran. Kata ini di negeri Arab sebelum Islam diartikan sebagai sebuah kekuatan buta yang tidak dapat dikendalikan oleh manusia. Kata ini dipergunakan al-Qur'a $>n$ dengan mengubah konsep takdir buta yang tidak dapat dielakkan menjadi konsep Tuhan yang memberikan ukuran atau potensi-potensi pada sesuatu untuk membuat sesuai dengan ukuran tersebut.
}

Jurnal Pendidikan Agama Islam

Volume 02 Nomor 02 November 2014

Hal $380-387$ 
nature trancangan-Nya yang tidak akan berubah selamanya.

Berdasarkan kenyataan diatas, setiap benda memiliki sifat-sifat tertentu dan bisa diukur maka unsur pengukuran dalam sains pada dasarnya menyingkap ukuran sesuatu atau benda yang sudah ditentukan Allah swt di alam. Sebagai ilmu kuantitatif sudah seharusnya sains dalam menangani proses-proses alamiah mendasarkan kepada metode ini. Jika tidak, tentu semua hasil eksperimennya tidak dapat dikaji ulang baik oleh yang bersangkutan maupun oleh saintis lainnya.

Unsur penting yang ketiga dalam kegiatan sains kealaman ialah menganalisis data yang dikumpulkan dari berbagai observasi atau pengamatan dan pengukuran pada gejala-gejala alamiah. Kemudian ditarik kesimpulan rasional dari masalah yang sedang diteliti. Pentingnya peranan akal yang rasional disamping unsur observasi atau pengamatan sejalan dengan petunjuk al-Qur'an seperti yang telah diuraikan sebelumnya. Karenanya, semua unsur dalam kegiatan sains cocok dengan kandungan al-Qur'an.

Adapun wahyu atau ilham kendatipun dalam pengembangan ilmu pengetahuan pernah ada, namun ia tidak dapat dipelajari oleh semua orang. Sebab itu ia tidak dapat dijadikan patokan umum sebagai dasar pengembangan sains natural yang mempunyai sifat keterbukaan sebagai ciri khasnya. Arti dari sifat ini ialah hasil kajian ilmu ini harus dapat diperiksa ulang oleh yang bersangkutan atau saintis lain dengan hasil yang sama. Justru itulah sains natural ini dapat dikatakan konsensus daripada seluruh ilmuwan yang bersangkutan.

Untuk memperkuat argumen di atas pernah terjadi negara bagian Amerika serikat, seorang ahli riset bernama 
Dr. B. Stanley Pons dan koleganya Dr. Martin Fleischmann dari Inggris pada bulan maret 1989 memproklamirkan penemuan barunya di bidang fusi nuklir. Menurutnya elektroda palladium dalam sebuah tabung berisis air berat dapat menghasilkan sejumlah besar panas. Semula dunia bergembira akan memiliki kesempatan emas untuk menghasilkan energi dalam jumlah besar dengan biaya relatif murah. Akan tetapi setelah para saintis berlombalomba mengkaji ulang peristiwa ilmuah ini mereka tidak menemukan hasil yang sama seperti yang dipeoklamirkan Pons Fleischmann, padahal ketika teliti ulang tersebut diyakini tidak mengandung kesalahan penjabaran dari teori penemunya. Sebab itu penemuan ilmiah ini tidak dapat direkomedir oleh para saintis lain dan dipandang tidak pernah ada.

\section{G. Strategi Penyampaian ayat-ayat al-Qur'an tentang Alam dalam Proses Pembelajaran}

Berbagai strategi pembelajaran dapat digunakan untuk menyampaikan ayat-ayat al-Qur'an, sehingga dapat diterima dan dicerna oleh para peserta didik. Tujuan penyampaian ayat-ayat al-Qur'an beserta tafsirnya ini dimaksudkan agar peserta didik dapat memiliki pemahaman bahwa ilmu dalam al-Qur'an sangatlah luas dan mendukung temuan-temuan ilmiah. Selain bertujuan agar peserta didik semakin yakin akan kebenaran al-Qur'an, kegiatan ini juga bertujuan untuk mempelajari al-Qur'an lebih lanjut, tidak hanya ayat yang disampaikan oleh pendidik. Dengan mempelajari lebih lanjut apa yang ada dalam al-Qur'an diharapkan peserta didik akan belajar lebih giat untuk dapat melakukan pembuktian- 
pembuktian secara ilmiah ilmu-ilmu yang terkandung di alQur'an. ${ }^{40}$

Pengintegrasian ayat al-Qur'an pada materi sains khususnya tentang alam memerlukan strategi yang berbeda dengan konsep ilmu tunggal. Dalam konteks integrasi, penyampaian ayat al-Qur'an ini dapat dipandang dari dua sisi, pertama konsep ayat al-Qur'an dianggap sebagai bagian dari konsep yang sama dengan ilmu sains itu sendiri. Kedua, ayat al-Qur'an dianggap sebagai konsep yang berbeda dengan konsep sains yang dijelaskan. Untuk pandangan pertama (integrasi konsep sejenis dapat mengaplikasikan model connected. Dan pandangan kedua dapat mengaplikasikan model integrated. Kedua model ini dapat divariasikan satu sama lain sehingga akhirnya diperoleh aplikasi strategi yang sesuai untuk diaplikasikan dengan variable-variabel lain dalam pembelajaran (kondisi siswa/ketersediaan media/material, dan lain-lain).

Misalnya saja pengintegrasian ayat al-Qur'an pada materi astronomi sebatas bertujuan pada aspek knowing/pengetahuan. Dalam aspek pengetahuan, murid memiliki pengetahuan mengenai berbagai hal yang berkenaan dengan pemahaman kandungan al-Qur'an. Untuk mencapai tujuan ini, pendidik dapat memilih metode ceramah, Tanya jawab, dan demonstrasi yang mengarah pada direct instruction.

Penyampaian ayat ini diharapkan merupakan bagian inti dari pembelajaran, meskipun bukan yang utama karena hal yang utama adalah konsep tentang alam yang berkaitan. Walaupun bukan yang utama tetapi tetap masuk kegiatan inti yang harus dilakukan konfirmasi terhadapnya. Penyampaian

40 Tim Penyusun, "Pendidikan Lingkungan Perspektif Pendidikan Islam", dalam Jurnal Pendidikan Agama Islam, Vol. 2 Nomor 3, 2014, 45. 
ayat ini dapat dimasukkan dalam kegiatan konfirmasi, sehingga lebih tepat kalau digunakan metode direct instruction, peserta didik mempunyai pemahaman yang sama tentang makna yang disampaikan. Untuk itu pendidik harus terlebih dahulu memahami dengan sebaik-baiknya apa yang akan dikonfirmasi ke peserta didik.

Direct Instruction dapat divariasi dengan penggunaan strategi yang menarik seperti penggunaan video pembelajaran, reading aloud, dan hafalan. Penjelasannya yaitu sebagai berikut: 41

1. Dengan video pembelajaran. Sudah banyak beredar videovideo tentang fenomena alam semesta yang dikaitkan dengan al-Qur'an. pendidik dapat memutar video tersebut dan member penjelasan atas apa yang ada di video. Dengan strategi ini, pendidik dapat terbantu dalam menyampaikan konfirmasinya sehingga apa yang disampaikan benar adanya.

2. Reading aloud. Dengan membaca, siswa akan dapat mengeksplor kemampuannya sehingga mampu memahami ayat-ayat terkait materi astronomi. Reading aloud ini dapat dilanjutkan dengan menghafal ayat yang berkaitan.

3. Hafalan. Peserta didik diminta menghafal satu ayat dan terjemahannya untyk ditunjukkan ke pendidik minggu berikutnya. Kegiatan ini dapat diintegrasikan dengan pelajaran lain seperti materi hafalan ayat.

\section{H. Penutup}

Penciptaan alam semesta dalam al-Qur'an dilengkapi dengan hukum-hukum Allah (sunnatullah) yang tidak akan mengalami perubahan dan penyimpangan. Oleh karena itu

\footnotetext{
41 Tim Penyusun, “Pendidikan Lingkungan Perspektif Pendidikan Islam”, 47. 
setiap manusia yang melaksanakan anjuran al-Qur'an agar memahami alam semesta dengan cara mengamatinya dengan alat indera atau dengan peralatan observasi, akal dan wahyu maupun ilham sehingga menyadari bahwa dibalik karya besar yang maha luas ini ada dzat yang harus diyakini dan disembah yakni Allah swt.

Berbagai teori tentang terbentuknya alam semesta pada dasarnya tidak bertentangan dengan al-Qur'an, namun hasil yang ditemukan dari observasi ilmuwan yang kealaman yang dibidangi sains dan teknologi lebih akurat dan lebih dapat diterima daripada hasil pemikiran-pemikiran yang lain yang bersifat spekulatif. Karena alam semesta termasuk masalah alam fisik tidak dapat dilakukan dengan berpikir spekulatif, sebab memang bukan bidangnya. Menempatkan porsi ilmu yang tidak sesuai dengan bidangnya akan melahirkan kerancuan dan kebenarannya akan diragukan.

Alam semesta adalah seluruh alam, baik fisik maupun non fisik. Pandangan ini sejalan dengan isyarat yang terkandung dalam kata al-samawat wa al-ardh wa ma baynahuma, yang berarti banyak alam, yang berbeda bentuk dan hukum-hukumnya antara satu dengan lainnya. Teori yang dihasilkan oleh para ilmuwan dan pakar, tentang bagaimana terbentuknya alam semesta ada dua, yaitu: Teori Keadaan Tetap (Steady-State Theory), Teori Dentuman Besar (Big-Bang Theory), dan teori Nebula.

Alam tunduk mutlak pada hukum-hukum Allah swt. Semua alam yang berjalan sesuai dengan hukumnya menjadi subyek sekaligus obyek pendidikan dan pembelajaran. AlQur'an memandang pengamatan indera sebagai saluran utama dalam memahami alam semesta. Namun dalam ayat-ayat lain, ditegaskan pula bahwa saluran ini belumlah cukup dan dibutuhkan saluran lain, yakni penalaran atau akal. Berbagai 
strategi pembelajaran dapat digunakan untuk menyampaikan ayat al-Qur'an, sehingga dapat diterima dan dicerna oleh para peserta didik.

\section{DAFTAR PUSTAKA}

A. Baiquni, 1991, Alam Ghaib Punya Hukum Sendiri, Pelita (18 Maret).

Abdul Hakim, Atang, 2007, Metodologi Studi Islam (Bandung: Rosdakarya).

Aly, Abdullah, 2000, Ilmu Alamiah Dasar (Jakarta: Bumi Aksara).

Bahreisy, Husein, tt., Kamus Islam Menurut Qur'an dan Hadith (Surabaya: Galundi Jaya).

Baiquni, Achmad, 2009, al-Qur'an dan Ilmu Fisika dalam Perspektif Pengembangan Tafsir al-Qur'an (Jakarta: UIN Syarif Hidayatullah).

Basri, Hasan, 2009, Filsafat Pendidikan Islam (Bandung: Pustaka Setia).

Daud Ibrahim, Marwah, 1999, Etika, Sinergi Ilmu dan Teknologi Masa Depan (Jakarta: Rosda).

Departemen Agama RI, 2009, Al-Qur'an dan Terjemahannya (Jakarta: Yayasan Penyelenggara Penterjemah dan Penafsir al-Qur'an).

Fu'ad 'Abd al-Baqiy, Muhammad, 1987, al-Mu'jam al-Mufahras li Altfazhal-Qur'an al-Karim (Beirut: Dar al-Fikr).

Ghulsya, Mahdi, 1998, Filsafat Sains Menurut al-Qur'an, ter. Agus Effendi (Bandung: Mizan).

Jauhari, Tanthawi, tt., al-Jawahir fi al-Tafsir al-Qur'an, Jilid I (Beirut: Dar al-Fikr).

Mawardi, 2004, Ilmu Alamiah Dasar, Ilmu Sosial Dasar, Ilmu Budaya Dasar (Bandung: Pustaka Setia). 
Muhaimin, 2001, Paradigma Pendidikan Islam: Upaya Mengefektifkan Pendidikan Agama Islam di Sekolah (Bandung: Rosdakarya).

Nasution, Harun, 1993, Akal dan Wahyu dalam Islam (Jakarta: Universitas Indonesia).

Shihab, Quraish, 1990, Hakikat Segala Puji dalam Surah al-Fatihah, Amanah, Nomor 110, 21 September.

Tim Penyusun, 2014, "Pendidikan Lingkungan Perspektif Pendidikan Islam", dalam Jurnal Pendidikan Agama Islam, Vol. 2 Nomor 3.

Taq al-Din Abi al-Abbas Ahmad Ibn Taimiyyat al-Harrani, tt., Kitab al-Radd 'ala al-Manthiqiyyin (Makkah: Dar al-Baz li alNasyr wa al-Tawzwi).

Zar, Sirajuddin, 1997, Konsep Penciptaan Alam dalam Pemikiran Islam, Sains dan al-Qur'an (Jakarta: PT. Raja Grafindo Persada). 